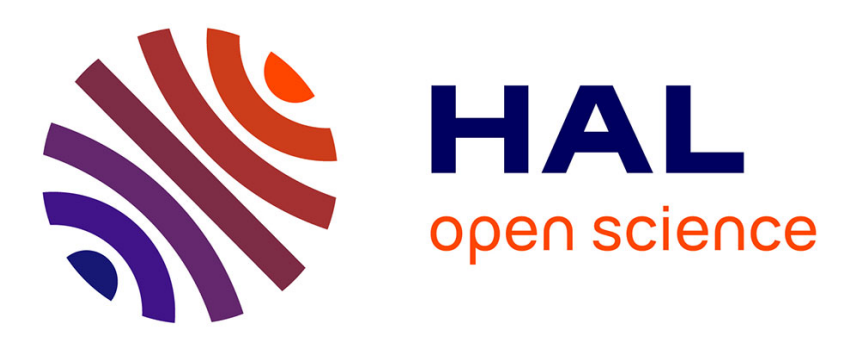

\title{
The Spread of Tax Resistance. The Antitax Movement in France in the 1970s
}

Alexis Spire

\section{To cite this version:}

Alexis Spire. The Spread of Tax Resistance. The Antitax Movement in France in the 1970s. Journal of Policy History, 2013. hal-02523234

\section{HAL Id: hal-02523234 \\ https://hal.science/hal-02523234}

Submitted on 28 Mar 2020

HAL is a multi-disciplinary open access archive for the deposit and dissemination of scientific research documents, whether they are published or not. The documents may come from teaching and research institutions in France or abroad, or from public or private research centers.
L'archive ouverte pluridisciplinaire HAL, est destinée au dépôt et à la diffusion de documents scientifiques de niveau recherche, publiés ou non, émanant des établissements d'enseignement et de recherche français ou étrangers, des laboratoires publics ou privés. 
The Spread of Tax Resistance

The Antitax Movement in France in the 1970s

\section{Alexis Spire}

In his landmark book devoted to ways of protests and to the repertoire of collective actions, Charles Tilly demonstrates that tax rebellions were constantly a source of unrest in rural France during the Ancien Régime and after the French revolution. ${ }^{1}$ However, what seems to be a French historical continuity reflects very different social structures under different historical regimes. The antitax movements vary according to the type of organizations that represent them (political parties, unions, or taxpayer organizations) but moreover according to the social classes. In this respect, the term "tax revolt," which is often used to talk about people's hostility toward the fiscal state, could be misleading as it implicitly attributes tax revolt to the grassroots people, or at least to the social class in conflict with the ruling power. In order not to limit the analysis to the working class, it would be better to use the expression "tax resistance," which includes every type of overt antitax complaints. Whereas most scholars explain fiscal revolts by the political and social conditions surrounding actions of individuals, ${ }^{2}$ this article links the "repertoires of collective actions" ${ }^{3}$ to antitax movements and the response of the state's civil servants. ${ }^{4}$

As a result, the fact that violence against the French tax administration waned should not be interpreted as the sign of a general consent but rather of a transformation of tax resistance itself. Whereas in the nineteenth century, most tax protests hoped to undermine the ruling power, tax resistance that continued at the end of the twentieth century aimed more at influencing tax policies than casting doubt on tax payment per se. Therefore, tax resistance should not only be analyzed as a strict rebellion against the state: ${ }^{5}$ First and foremost, its goal is to negotiate tax 
expenditures from state authorities, allowing taxpayers to reduce their tax burden within the limits of the law. ${ }^{6}$ Under certain circumstances, tax resistance may give birth to alliances between citizens who want to weaken the power of the state and the middle class expecting its protection, as Isaac William Martin shows it in his book on tax protest in California at the end of the 1970s. ${ }^{7}$

In France, self-employed and small businessmen dominated antitax movements throughout the second part of the twentieth century. The antitax demonstrations allowed them to strengthen their sense of belonging to an intermediary group between workers and employers, and to distinguish them from the middle classes' civil servants. Whereas in Italy, the mobilization of the traditional middle classes was oriented against the left, it was used in France to criticize and to limit the state power. ${ }^{8}$ Craftsmen and shopkeepers fought the French state and, in the process, cemented a new collective class consciousness.

The antitax movement triggered in 1969 by Gérard Nicoud - a young charismatic café owner - was immediately viewed as a resurgence of Poujadism. Pierre Poujade was the leader of the huge antitax movement, which flourished in France between 1954 and 1958 and which obtained 12 percent of the vote in France's parliamentary elections in 1956. In the 1970s, rebellions drew on the same social base, but they differed from the Poujadist movement in important ways. The protests of the 1970s lasted much longer (almost ten years), lacked a political outlet (no deputy directly claimed to represent it), and resorted to more violent means.

From a systematic use of the archives of the central administration of the General Tax Office, I first depict the various forms of the tax revolt, which broke out in the French département of Isère in 1969 and lasted until 1978. Leaders initially organized violent demonstrations against tax offices. Then they campaigned to stop paying the patente, a special tax paid only by the self-employed. Facing the threat of fines, they also called for out-of-court petitions and for systematic legal recourses. Eventually, after failing to use legal means and to 
take advantage of French bureaucratic procedures, they turned to violent actions and demonstrations. To protest against the wide discretionary power of tax administration and its power of "inquisition," they intimidated tax inspectors and sometimes committed physical violence against them.

In order to understand antitax mobilizations, one needs to take into account the reactions of the state (government ministers and the judiciary) as well as the media. Confronted by the antitax movements of the 1970s, leading government officials showed compassion and gradually accepted the fact that the coercive power of the state had to be more limited during the collection process. During violent protests against tax officials, police avoided confrontation and rarely arrested troublemakers. Judges also showed compassion with key antitax players, even when the latter were clearly identified. Likewise, government officials, during public speeches, distanced themselves from tax officials' practices of control. By doing so, they wanted to show their support for the antitax movement and thus get closer to self-employed middle-class workers.

The press also helped make violence against tax officers more legitimate. By describing tax audits as morality tales pitting small-business owners against an intrusive government, many journalists fueled the protest movement, helped broaden its social base, and provided a receptive audience. Often described by the press and by some high-ranking civil servants as a legitimate reaction against the arbitrary methods of the fiscal administration, the social turmoil of shopkeeper activists provides the opportunity for some dominant groups to unite with an antitax movement that was until then associated with a reaction of backward people against modernization. Tax resistance could thus be transformed into a general social unrest, by means of "the temporary alliance between the mob and the elites" as Hannah Arendt has described it. ${ }^{9}$ 
French specificity of tax resistance could be summarized in three points. First, French tax opponents rallied around professions, and not around living communities like in the United States. Second, they took the French administration and its inquisitorial power as target, but at the same time, they also claimed for better protection from the state. Eventually they still demonstrated a great attachment to the French principle of equality. Tax opponents used the ambiguity of the word "equality" to broaden their audience. Presenting themselves as the advocates of the weak against the strong, they won the greatest possible number of taxpayers to their cause. ${ }^{10}$

$<1>$ The Forms of Antitax Mobilization

Gérard's Nicoud movement, inspired by poujadism, owed a large part of its success to the fact that it presented itself as a custodian of Mom and Pop stores against hypermarkets. However, this movement did not directly target any hypermarket. Violent acts were all directed against government symbols. Use of violence was linked to the social context triggered by the events of May 1968. In the 1970s, violence was widespread and often occurred during sit-ins, barricades at universities, farmers' marches, and factory workers' strikes.

$<2>$ Demonstrations

Gérard Nicoud, the owner of a small French "café-restaurant" in a village in Isère, became well known to the public when he came to embody the resistance to the 1966's shopkeepers and craftsmen's health-law insurances. During his first meeting, which rallied fifteen thousand people 
in Grenoble in February 1969, he focused his speech on the insurance and pension schemes to denounce the disadvantage for shopkeepers and craftsmen in comparison with other wage earners. From the very beginning, his speeches gave the names of the alleged culprits: the "Ministry's technocrats" and other bureaucratic elites. Even though the tax issue was not among the claims of the movement, Gérard Nicoud chose for its first target what seemed to perfectly embody the state's power-a tax office. As Stanley Hoffman has pointed out, "It is a law of French political life that the revolts against proletarization take the form of an insurrection against the state." ${ }^{11}$ On April 9, 1969, members of Nicoud's movement, the Information and Defence Committee (CID), entered a tax office and took possession of many documents and archives that they kept as bargaining chips. Nicoud was held liable for what happened; he was sent to jail and released a few days later. However, meeting after meeting, his movement became more popular. On October 13, 1969, twenty thousand attended the meeting and even forty-five thousand on March 9, 1970. In fact, tax resistance became a major element of the movement, especially after the adoption of a new law, on January 6, 1970, which improved the health insurance system of the self-employed. The government's goal was to forestall the revolt, but the movement continued and put tax reforms at the forefront.

Since then, Nicoud's advocates systematically launched a series of actions that directly targeted tax offices and its employees. In Brittany, for instance, on March 25, 1970, a craftsmen and shopkeepers' demonstration triggered an attempted petrol-can fire that aimed at the tax collector's office of Bannalec. ${ }^{12}$ Without actual coordination and organization supervision, threatening and violent operations multiplied during tax audits. False bomb threats, anonymous letter, and phone calls were used; some tax officers' private homes were even broken into and tax collector's offices were vandalized. Between 1969 and 1972, the General Tax Management Bureau estimated that 350 incidents had occurred, 82 of which were objections to tax audits and 
265 were demonstrations. ${ }^{13}$ Moreover, the Regional Tax offices listed other 150 misdemeanors, mainly in the Rhône-Alpes département, in Marseille, and in southwest France. On the whole, unrest areas resembled the voting zone of poujadism.

During this first antitax period, violent acts occurred with greater frequency, following a "parochial and patronized repertoire," according to the words of Charles Tilly to describe French

protests between 1650 and $1850 .{ }^{14}$ Like the former French Jacquerie, the uprisings consisted of spontaneous and local meetings, which most of the time aimed to help a local shopkeeper grappling with the French tax administration.

$<2>$ The "patente Strike"

In 1971, the CID merged with the UNATI (the French national union for the self-employed), and became CID-UNATI. This new trade union committed itself to more peaceful mobilizations. The CID-UNATI sought to expand its influence by asking craftsmen, shopkeepers, and the selfemployed middle class <ok?yes>to start a "patente Strike"-(the patente was a business licence tax introduced just after the French Revolution. This form of mobilization, also implemented by Poujade twenty years earlier, was inspired by the labor movement, which had developed since the nineteenth century. Actually, denunciation of the workers' exploitation was turned against the state authority and typical slogans of the Marxist phraseology twisted like this slogan proved it: "Taxpayers of all parties, unite!" The resemblance of this protest with the forms of mobilization and organization of the labor movement was undoubtedly a specific feature of the French antitax movement. 
For the CID-UNATI, the patente was a means of extending the movement's audience to every self-employed worker who denounced the discriminatory nature of the tax. Instead of attacking the French tax system as a whole, Nicoud demanded that local governments be financed by other levies. ${ }^{15}$ In every French département, public meetings were attended by legal counselors who explained to the audience "how to legally use the law." ${ }^{16}$ Letter templates were given out to the attendees so that they could file personal claims for the years 1971-72. They were advised to indicate that the latest revision of the housing rental value dated back to 1941 . Some farmers' organizations, especially in the French département of Finistère, joined the movement. In the département of Hérault, on December 18, 1972, the Chamber of Commerce adopted a unanimous deliberation demanding the abolition of the patente.

As the administration refused to follow up the claims, the CID-UNATI asked selfemployed people to file appeals to the court. However, this litigation campaign gathered fewer followers. As state authorities registered more than 5,600 applications for review, only 628 petitions were lodged with the Administrative Court. The CID-UNATI was thus forced to abandon the strike during the summer of 1973. In December, the Parliament passed the "Royer law" (for Jean Royer, the Minister of Commerce and Artisanry), which gave small businesses greater protection. And two years later, the patente was replaced by a professional tax that allowed artisans to pay 53 percent less than before. Then the audience of the CID-UNATI decreased. Gérard Nicoud tried to revive it with new violent actions, especially against tax officers. 
$<2>$ Violence Against Tax Officers

In 1975, the CID-UNATI launched a new campaign against the increasing number of tax investigations. Indeed, between 1969 and 1975, the number of tax audits almost doubled from twenty-five thousand to forty-five thousand. Mom and Pop shops that did not keep their books of account were particularly targeted. The CID-UNATI used this escalation of tax audits to justify their use of violence. Between January and April 1975, thirty-four tax offices were attacked, either by angry protestors or through a series of bombs or Molotov cocktails. ${ }^{17}$ From the destruction of tax offices, the movement quickly began to physically attack tax collectors. In Moselle, on April 24, 1975, the premises of a tax office were robbed, and a few days later hooded men broke into a tax officer's private home, stole his files, and then sprayed the place with petrol and fled. ${ }^{18}$ At that time, many tax officers did not have offices and were often forced to work in their own homes, but this situation enhanced confusion between the individuals they embodied and the state authority they represented. The target of the tax revolt was no longer restrained to tax offices. Violent acts were directly aimed at agents through anonymous telephone calls threatening themselves and their families. On May 14, 1975, about twenty protestors who claimed to belong to CID-UNATI entered a tax office and asked to see the tax inspector who audited one of their workmates. They beat him up and punched him in the face and destroyed a few files. A police investigation was opened, but as none of the participants could be identified, the case was dismissed and the tax administration did not appeal. At the same time, Gérard Nicoud advocated the creation of units in each département that could react immediately and strongly to tax-audit units- "an eye for an eye, a tooth for a tooth." ${ }^{19}$ During a meeting in Brittany on October 6, 1976, he even declared that "from [then] on, we will hold tax officers 
exclusively liable for, either they are tax collectors, tax auditors etc, and not anymore the tax administration. Anonymity [was] now over." Nicoud did not hesitate to compare tax officers' working methods with those the Gestapo and announced the creation of antitax units. ${ }^{20}$

As the French government gave many artisans and shopkeepers with the Royer Law and the replacement of the patente what they wanted, it contributed to the decline of Gérard Nicoud's movement. But the antitax atmosphere that developed in France in the 1970s was far from being limited to craftsmen and family business owners alone. Doctors, veterinarians, lawyers, and chartered accountants also reacted strongly to tax audits. In a 1977 report, the Inspection générale des finances, in charge of monitoring the whole tax administration, indicated that "numerous professionals [did] not accept to cooperate with tax officers and [justified] their refusal in the name of professional secrecy." 21 Tax aversion spread during this time, reaching professions beyond shopkeepers. Furthermore, tax resistance was not limited to a conflict against the state's intervention. On the one hand, the state authority was violently questioned; however, on the other hand, shopkeepers, craftsmen, and small-size company owners asked the state to protect them against the modernization of the French economy. This tense relationship, between protest against the state authority and official calls for state protection, was undoubtedly one of the major characteristics of the antitax movement in France.

$<1>$ Civil Servants and Politicians Turn to Tax Resistance

During the 1970s, the antitax atmosphere shifted from a movement to the self-employed, managing small-size companies, to a larger-scale movement, transforming the tax issue into a national concern. As proven by Joseph Gusfield, ${ }^{22}$ this new status implied the intervention of 
various institutions. In the past, shopkeepers and craftsmen's associations were, with reference to Gusfield's terms, "the major owners" of the antitax issue. As soon as Gérard Nicoud's advocates started violent actions against the symbols of the state, many key players rallied to the cause. The administration's elites-attorneys, high-ranking civil servants, politicians, deputies, senators, members of the government, on one hand, and the media, on the other hand, played a major role in the expansion of the tax-resistance movement.

$<2>$ High-Ranking Civil Servants and the Antitax Revolt

Whereas the Poujadist movements of the 1950s closely collaborated with the heads of the préfectures and tax-office representatives, ${ }^{23}$ the strikes headed by the CID-UNATI triggered more uncertain reactions from the state's representatives. The wrecking of the general tax office in the Aude département on March 17, 1975, was a clear illustration of the change. On the sidelines of a wine-grower demonstration in Carcassonne, a group of a hundred people managed to enter the tax office premises after breaking down one of the doors with a pile driver. The building's windows were destroyed, the entrance hall ransacked, the furniture was damaged, and tax files were strewn about and burned. In a letter to the Home Office, the Ministry for National Economy was surprised that the police only arrived on the premises twenty minutes after the beginning of the attack, whereas many days before the march, the chief treasurer and paymaster had informed the préfet about how the demonstration was likely to end up. The Home Office's answer spoke for itself: To prevent the demonstration from turning into a street riot, "the contingents of the police gathered along the route of the demonstration were not supposed to be seen by the demonstrators" and were thus forced to act discreetly. <author: perhaps rework the 
next two sentences for clarity> Such a representation reveals a flexible conception of maintenance of Law and order. ${ }^{24}$ : they tolerated some behavior from the self employed middle class , allegedly the electoral fermenting base of the ruling power and applied the rule for the rest.

However, the reluctance to punish assaults against tax offices and their representatives spread even to tax high-ranking civil servants. During the nights of June 2 and 3, 1977, for instance, some files were stolen from the Tax Audit General Unit in Cannes, but the regional authorities refused to press charges and the affair did not go any further. When damages were larger, the French administration took civil actions: On August 15, 1976, for instance, a fire was started in the premises of the First Tax Audit General Unit in Paris and official files were destroyed. This time, a charge was pressed, but the case was closed because the perpetrators could not be identified. When one referred a matter to a court, the justice system also showed compassion regarding the antitax movement protagonists. The sanctions to punish the violent actions against tax officers were indeed very lenient, as Table 1 shows.

<comp: insert Table 1 about here> 
Table 1. Judgments pronounced for unlawful deeds against tax officers

\begin{tabular}{|c|c|c|c|}
\hline Date & Nature of the incident & Judgment in jurisdiction & Appeal hearing \\
\hline March 25, 1970 & Anonymous threatening letter & $\begin{array}{l}1 \text { month prison suspended sentence } \\
\text { and a fine of } 500 \text { French francs }\end{array}$ & \\
\hline June 18,1970 & $\begin{array}{l}\text { Outrage and assault and battery } \\
\text { (grievous bodily harm) }\end{array}$ & $\begin{array}{l}8 \text { days prison suspended sentence and } \\
\text { a fine } 500 \text { of French francs }\end{array}$ & \\
\hline June 25,1970 & Abuse and assault and battery & 15 days of imprisonment & \\
\hline October 19, 1970 & Violence, detention, and theft & $\begin{array}{l}\text { Prison sentences of } 18 \text { months, } 6 \\
\text { months, and } 2 \text { months }\end{array}$ & Decision upheld \\
\hline December 3, 1970 & $\begin{array}{l}\text { Objection to tax audit, theft, } \\
\text { and concealment }\end{array}$ & 2 months suspended sentence & $\begin{array}{l}1 \text { month } \\
\text { suspended } \\
\text { sentence }\end{array}$ \\
\hline December 14,1970 & Violence, assault, and battery & 15 days suspended sentence & Decision upheld \\
\hline January 25, 1971 & Bomb attack & $\begin{array}{l}5 \text { years of prison, including a } 4 \text {-year } \\
\text { suspended sentence }\end{array}$ & \\
\hline May 6, 1971 & $\begin{array}{l}\text { Objection to tax audit, and } \\
\text { assault and battery }\end{array}$ & 4 months suspended sentence & \\
\hline June 22,1971 & Assault and battery & Fine of 100 French francs & \\
\hline August 22, 1971 & $\begin{array}{c}\text { Violence, outrage, assault, and } \\
\text { battery }\end{array}$ & 6 months suspended sentence & \\
\hline March 1, 1972 & Grievous bodily harm & Non-suit & \\
\hline April 18, 1972 & Assault and battery & 3 months suspended sentence & \\
\hline May 23, 1972 & Assault and battery & Fine of 600 French francs & \\
\hline July 21, 1972 & $\begin{array}{l}\text { Objection to tax audit and oral } \\
\text { intimidation }\end{array}$ & 8 days suspended sentence & \\
\hline April 13, 1973 & Violence, assault, and battery & Fine of 200 French francs & \\
\hline May 9, 1973 & Assault & 2 months suspended sentence & Decision upheld \\
\hline May 15,1973 & Assault and corporal damage & 3 years of prison & \\
\hline June 19, 1973 & Assault and battery & Fine of 600 French francs & \\
\hline June 26, 1973 & Assault and battery & 1 month suspended sentence & \\
\hline July 3, 1973 & Outrage and violence & Fine of 100 French francs & \\
\hline
\end{tabular}

Source: CAEF 1A 284/1. 
An analysis of the main judgments against culprits of assaults against tax officers reveals that judges appeared to be quite lenient. Most of the time, the perpetrator was given a suspended prison sentence. Out of the twenty files, only four cases appealed the decision. In three cases, the decision was eventually upheld, and in the last one the sentence was lessened. The lightness of the sentences contrasted with those that were pronounced against the Poujadist followers fifteen years earlier. The comparison with the Calvados farmers' case in October 1955 is blatant. Opponents of the tax ransacked a tax office and burned the files. As a result, they were condemned to up to eight months in prison and were then forced to appear before the Assises. ${ }^{25}$ Against the Poujadist movement, the authorities launched charges, searched houses, and arrested people who sometimes only encouraged the nonpayment of tax. ${ }^{26}$ For more serious misdemeanors, Nicoud's supporters had their sanctions suspended more often.

From 1975 onward, assaults intensified, but sentences remained light. Thus, on November 23,1976 , a female tax inspector was hit on the head with a broken bottle after she discovered that a vehicle did not carry the automobile registration stamp. The perpetrator was condemned to an eight-month suspended sentence and had to pay damages to the plaintiff. Sometimes this tribunal leniency became more visible, through the judges responsible for overseeing the terms and conditions of a prisoner's sentence, as in the case of this tax inspector, who was given a rough time:

$<e x t>$

On April 25, 1973, a tax inspector had just finished examining the accounts of Mr. L., a farm products tradesman, and was driving on his way to Marseille. After driving a few kilometers, a car passed Mr. L. and cut in front of him, while a second vehicle prevented him from backing up. Three men, among them Mr. L., forced the tax inspector to sit in the back of his own car and drove him to a secluded quarry, where they beat up. After 
threatening him and his family with death and buggery, they forced him to sign a promise to limit the audit to the amount of 10,000 French francs and to accept a 10,000 franc debt to Mr. L. They also forced him to sign a declaration in which he admitted the rape of one of Mr. L.'s relatives. The case was judged by the original criminal court of Aix-en-Provence, condemning Mr. L. to a three-year prison sentence, but the judge responsible for overseeing the terms and conditions of the sentence released him sixteen months later.

<end ext>

Interviewed on this case, the ministry of justice explained the decisions given by the judge as "a will of appeasement" regarding "some socio-professional classes who publicly expressed their wishes for fiscal reforms that they considered necessary to the improvement of their working conditions." 27

When one raised the question about violence during debates in Parliament, politicians also proved to be very compassionate. Their reactions had nothing to do with the indignation triggered by the deeds of Poujadists twenty years earlier. Whereas actions against auditing civil servants became more violent and more systematic, the state representatives' speeches evolved considerably, as this diatribe from Maurice Blin, a senator of the UDF Party (center-right) proved: "Why, for a while now, have tax inspectors adopted an inquisitorial and insulting tone when auditing the most modest companies? Some of them seem to voluntarily lead their examinations of accounts in a provocative way; to such a point that I am to ask myself if they do not seek, beyond the respect of the law, to arouse resentment in the business world, resentment which could, in the future, be capitalized on some other purposes." 28 
In his claim, Senator Blin implicitly suggested that the incidents during tax audits were directly caused by tax inspectors themselves. Concerns to reassure some taxpayers in order to preserve - or acquire - voters whose ballots were necessary for parliamentary elections led some politicians to side against tax officers. On May 9, 1976, Prime Minister Jacques Chirac followed suit, and even stigmatized "the excessive zeal" displayed by tax officers. Moreover, he denounced the excessively fussy audits and their lack of goodwill to admit some arguments presented by audited taxpayers. Such an accusation was also made by Lucien Neuwirth, a Gaullist deputy, general secretary assistant of the UDR, and the writer of a pamphlet with an evocative title The Tax Plague. In this book, he argued that the voters had been deprived of their power by the French tax administration, especially because of "some tax officers and punchy political activists. ${ }^{, 29}$ In this controversy, left-wing party leaders, however, were far from standing for tax auditors in order not to cut themselves off from the self-employed middle classes. On February 12, 1976, at the socialist Head Office, a CID-UNATI delegation led by Gérard Nicoud met the opposition party leader François Mitterrand, who concluded the meeting with the wish that the two organizations remain in close contact. ${ }^{30}$

During President Valéry Giscard d'Estaing's seven years in office, many key political players were suspicious of tax officers. ${ }^{31}$ In addition to the centuries-old fear of the intrusion of the state in French private lives, one could then suspect that the political use of tax audits were $<$ ?yes>made by inspectors who had fully adopted an antibusiness ideology.

$<1>$ The Role of the Media in the Spread of Antitax Resistance 
The media largely contributed to the national hearing on the antitax movement, <ok?yes> which, in the beginning, looked like a disorganized and instinctive reaction to the power of the state. From the beginning of the 1970s, the CID-UNATI tried to spread the idea that there was a relation of cause and effect between the intensification of the tax audits and some suicides among small shopkeepers. In order to have ordinary stories disclosing social problems, the news had to be written in a scandalous way that would evoke empathy for the victims and revenge against the culprits.

The idea to link tax duties to deadly ends with the potential to induce defenseless shopkeepers to kill themselves was not a new one. As soon as 1951, Le Bon Sens, the French newspaper of a taxpayer association, every month published a summary of the "tax obituaries," which listed all the names of shopkeepers who had committed suicide for the nonpayment of their taxes. ${ }^{32}$ Whereas few people read those articles, they were in the 1970 s taken up by the regional and national press media. Using a scandalous tone, the CID-UNATI leaders relied on some cases in which shopkeepers committed suicide after being notified of a future adjustment of tax, to justify reprisals against tax officers. From 1975 onward, many journalists resorted to this style of indignation. In writing articles of painful tax audits in which the readers were called to witness, many journalists allowed the antitax movement to widen its grassroots base:

$<\operatorname{ext}>$

A father of 8 children, Bernard Anne, a small self-employed builder in the département of La Manche, was taxed on an empirical assessment system. On November 29, 1977, two tax inspectors came to his house to examine his business accounts. During this first interview, he explained to them that he knew absolutely nothing about bookkeeping and that he did not keep accounts books. Two months later, he got a notification of a tax adjustment of 15,000 francs. However, the self-employed worker, who had mixed up 
some figures, told his wife that he had to pay 50,000 francs and killed himself on Christmas Eve. ${ }^{33}$

<end ext>

Local newspapers were all the more prone to denounce tax audits and the blindness of the civil servants to the distress of the citizens<?yes>. La Tribune de la Manche, a French newspaper, stood up for an honest worker "murdered by an inhuman administration system." ${ }^{34}$ In the same tone, La Manche Libre, another newspaper, associated the French administration with "a faceless organization" that crushed "Mankind." 35 In addition to this human indignation, national newspapers used more political arguments. With reference to this same piece of news, Michel Tardieu, one of the first stock market commentators on television in the 1970s, denounced the new "terrorism orchestrated by the French administration." ${ }^{36}$ Regarding a similar issue, the newspaper Le Monde related the story of a taxpayer who killed himself because he was “dishonored" after being audited. ${ }^{37}$ These tax-audit stories advertised by shopkeepers' guilds played a dual role: they were a means to create compassion for the self-employed by depicting them as victims of the arbitrary tax system. Stories also allowed the antitax sentiments to spread into the society. The title of the article "The Tax Dragoons," published in the French magazine Le Point, showed the atmosphere of the time. A journalist reported the tax audit of a wine merchant who was described as a "family-business owner, with twenty five employees and 17 million French francs of turnover, like France has in their thousands." ${ }^{38}$ The comment turned to more political grievances when it denounced "arbitrary and offending fights" and raised the question, "What can be done against a law-mannered force?"

Newspaper articles did not limit their contents to the stories of shopkeepers who came up against account examinations, but also put the blame on the French tax administration for being 
omniscient and omnipotent. "The French citizens do not know that almost every one of their actions and their families' are being kept up to date by the French tax services." Valeurs actuelles, a French magazine, named one of its articles "The Tax Auditors' Safari," using an expression coined by Gérard Nicoud. In this article, the journalist described the defenseless shopkeeper as a victim, whereas the tax auditor was portrayed as a powerful man with inordinate powers. Le Journal du dimanche, a popular weekly newspaper, dedicated a special feature illustrated with a series of anecdotes from taxpayers, all self-employed: a fishmonger, an industrialist, a restaurant owner, who explained all the vexations they had to go through during their tax audits. The journalist finished the article by explaining: "When dealing with tax auditors, the French taxpayer, like in La Fontaine's tales, [was] more disarmed than the lamb in front of the wolf." The portrayal of the tax auditor as a torturer was sometimes intensified by suspicions of politicization. In some newspapers, tax auditors were suspected of serving left-wing political interests instead of keeping a neutral position, which should prevail when working for the public service.

Television also played a key role in broadcasting this antitax message on a national scale. Indeed, unlike the Poujadist era of the 1950s, this movement led by Gérard Nicoud spread in a highly television-related media context. Thus, on October 4, 1975, Nicoud was given free reins to explain on a television program his grievances against tax auditors. He vehemently concluded his speech: "You know that the dream of the tax Administration is to open fully detailed files on every French citizen. So, we took the problem the other way and created personal index cards where one can read: the address, the number of children, the mistress (if there is one), and the political party the tax auditors belong to.” The television anchorman, Philippe Bouvard, answered in a smarmy way: "I don't know if this is effective, but it is rather funny." Afterward, Nicoud became a regular television guest and conveyed his antitax phraseology. Interviewed on the France 3 television news program on February 26, 1976, he compared tax-audit teams to the 
Gestapo and officially asked the French government to suppress them. When a bookseller committed suicide after being tax-audited, Nicoud urged the government to dismiss tax auditors and claimed that he would bring an action for involuntary homicide. He put it bluntly: "Tax auditors with tax forms and decrees instead of a heart and who do not hesitate to use any method possible: intimidation, blackmail, provocation. . . . To a certain extent, this is no longer suicide, it has become murder." 39

Journalists' interest in a rather small antitax movement can be explained by the scale of the actions they took (especially when it came to the ransacking of tax offices) and <please clarify $><$ by connecting trivial events to big social and political issues emphasizing the social and political impact of trivial events.> The fascination for stories of shopkeepers driven to despair after expensive tax-audit penalties was a means to create compassion in the readers, who swiftly identified themselves as victims. It was all the easier that they saw themselves in the place of taxpayers subjected to the French tax administration.

Unlike Pierre Poujade's movement, the CID-UNATI never tried to have its members run for the French Parliament. However, it benefited from a more careful ear from the political elite. In July 1975, the change of the licence tax (patente) into a business tax (taxe professionnelle) provided the opportunity to grant new guarantees to the self-employed middle class, which was seen as President Giscard's electoral base. In the same year, the president welcomed Gérard Nicoud to the Elysée, ${ }^{40}$ where<?no, "when" (or "while") is better> he was liable to many convictions for assault and battery against civil servants and buildings. A few months later, he announced the creation of the "Inspection générale des services," a checking unit in charge of monitoring the tax auditors at work. ${ }^{41}$ In doing so, he implicitly attributed the violent acts to the tax auditors and cleared the antitax movement leaders. Eventually, three reasons can explain why government officials and political parties responded to the Nicoud movement more positively 
than the Poujadism. First, government leaders may have come to fear the consequences of harsh repression after the experience of both Poujadism and the events in 1968. Second, during the 1970s, the political balance between left and right had made the competition between the main parties extremely tight and pressure groups gained a lot of influence. Neither the Gaullists nor the Socialists (nor the Communists) could afford to alienate shopkeepers and artisans, whereas it was less costly during the 1950s. Third, some government elites may have come to see tax resistance as a convenient, if unintended, force of support for modernizing the tax system.

\section{$<1>$ Conclusion}

Even if Gérard Nicoud's movement faded away at the end of the 1970s, it contributed to the spread of an antifiscal frame of mind that reached the whole of French society. From that time, the claim for cheaper tax was no longer the slogan of a handful of self-employed people suffering from the modernization of the economy, but a public issue reaching all social classes, and quickly legitimized by French intellectuals. Some, in the name of political understanding, backed the movement to denounce the "central bureaucratic institutions" and a "tax bulimia."42 Others, in the name of economic modernity, used it to extol the virtues of limited government. ${ }^{43}$

The French specificity of the tax-resistance movement appears clearly when compared to the features of the antitax movement in the United States in the same period. In 1978, a Californian taxpayer movement, which called for a tax ceiling, managed to get 1.5 million signatures under the name of "Proposition 13." Actually, the petition was ratified by two-thirds of the voters and added a maximum market-value property-tax ceiling of 1 percent to the state constitution. The California revolt drew on two combined effects: the decades-long campaign by 
radical antitax activists and the increasing dependence of local government services on the local property tax and on the changes in the real estate market. Beyond the unprecedented influence of the Californian referendum, the first difference between the two movements originated from the way the movements started. In the United States, mobilization for action before the vote on "Proposition 13" was based on community organizations, which allowed the movement leader Howard Jarvis to unite working-class taxpayers and wealthy entrepreneurs around the denunciation of the waste of taxpayers' money by states' officials. In France, the social class to which people belonged has shaped their tax resistance. The CID-UNATI described itself as a professional organization, objecting to every type of political engagement (this was why it always rejected connections with the Poujadist movement). The second difference stemmed from the taxation power of the French state. In the United States, the antitax mobilization nourished itself with the opposition between the States (in this case California) and the federal state bureaucracy. The California revolt was a local cross-class coalition, but it led the way to wider forms of tax resistance, even against the federal government, and became part of Ronald Reagan's antigovernment politics. In France, tax < resistance? Yes > mingled or even came to shape with the opposition to the tax administration and its representatives. Eventually, <please clarify $><$ antitax mood developed in the United States in the name of budget waste, > whereas in France it was the inquisitional power and the inequalities between the "weak" and the "strong" that became a battle issue. ${ }^{44}$

Despite those differences, the two movements have a characteristic in common: in both cases, tax resistance stemmed from the working and the middle classes, who claimed change in the name of a greater social justice. In California and in France, the mobilization was not only a tax revolt but also a movement for social protection from the market. They wanted to be protected in the French case from economic modernization and Big Business and in the American case "from income shocks that resulted from the rising price of housing." 45 On both sides of the 
Atlantic, the political parties interpret these movements in accordance with their interests: they focused on the opposition to any tax rate increase and overlooked the claim for protection that each movement maintained with their state authority.

National Center for Scientific Research (CNRS)

$<1>$ Notes

${ }^{1}$ Charles Tilly, The Contentious French (Cambridge, Mass., 1986), 156, 242, 386.

${ }^{2}$ David Lowery and Lee Sigelman, "The Tax Revolt: Eight Explanations," The American Political Science Review 75, no. 4 (1981): 963-74.

${ }^{3}$ Tilly, The Contentious French, 390.

${ }^{4}$ Those reactions can greatly vary according to eras and social elements as the recent works on the sociology of mobilizations show. See, for example, Repression and Mobilization, ed. Christian Davenport, Hank Johnston, and Carol Mueller (Minneapolis, 2005).

${ }^{5}$ This point of view is, for instance, developed by Richard A Musgrave in "The Tax Revolt,”Social Science Quarterly 59 (1979): 697-703.

${ }^{6}$ Christopher Howard, The Hidden Welfare State: Tax Expenditures and Social Policy in the United States (Princeton, 1997).

${ }^{7}$ Isaac Martin, The Permanent Tax Revolt: How the Property Tax Transformed American Politics (Berkeley and Los Angeles, 2008).

8 Suzanne Berger, "The Traditional Sector in France and Italy," in Dualism and Discontinuity in Industrial Societies, ed. Suzanne Berger and Michael Piore (Cambridge, 1980), 112.

${ }^{9}$ Hannah Arendt, The Origins of Totalitarianism (New York, 1976), part 2, 326-40.

${ }^{10}$ I would like to thank Herrick Chapman for his suggestions and corrections; any remaining errors are my own. 
${ }^{11}$ Stanley Hoffmann, Le mouvement Poujade (Paris, 1956), 22.

12 See the files deposited by the Ministry for the National Economy and Finances (MINEFI) in the Center of Economic and Financial Files at Savigny-the-Temple, 1A 284.

${ }^{13}$ Report to the Ministry of Economy, 14 May 1973, CAEF 1A284/1.

14 Tilly, The Contentious French, 392.

${ }^{15}$ See the national journal of self-employed workers, L'objectif, no. 26 (November 1972).

${ }^{16}$ Center of Archives of Economic and Financial Files (hereafter CAEF) B6 5361.

${ }^{17}$ CAEF 1A284/1.

${ }^{18}$ CAEF B51 974.

${ }^{19}$ CAEF $1 \mathrm{~A} 332$.

${ }^{20}$ CAEF B51 976.

${ }^{21}$ Inspection général des Finances, Les réactions du public face au contrôle fiscal en 1977, CAEF B 51979.

${ }^{22}$ Joseph Gusfield, The Culture of Public Problems: Drinking, Driving, and the Symbolic Order (Chicago, 1981).

${ }^{23}$ In a circular letter dated 3 December 1955, the Minister of Interior drew the préfet's attention to the necessity to clamp down quickly and strongly on objections to tax audits; cf. Departemental Archives of the North, 1008W34.

${ }^{24}$ See Donatella Della Porta and Olivier Fillieule, "Policing Social Protest," in The Blackwell Companion to Social Movement, ed. David A Snow, Sarah A. Soule, and Hanspeter Kriesi (Malden, Mass., 2003), 217-40.

${ }^{25}$ BB18 4194 Archives nationales Paris.

${ }^{26}$ Hoffmann, Le mouvement Poujade, 132. 
${ }^{27}$ Letter from the Minister of Justice to the Minister of Economy, 25 March 1975, CAEF 1A $284 / 1$.

${ }^{28}$ Maurice Blin's speech delivered to the French Senate, 21 November 1975 (Journal official de la République française, 3 551).

${ }^{29}$ Lucien Neuwirth, Le fléau fiscal (Paris, 1977), 135.

${ }^{30}$ See the report of the meeting in L'objectif, no. 60 (March-April 1976).

${ }^{31}$ On this topic, see Nicolas Delalande and Alexis Spire, Histoire sociale de l'impôt (Paris, 2010).

${ }^{32}$ See, for example, Le Bons sens, no. 2 (June 1951).

${ }^{33}$ This case and its exploitation by the media are tallied in CAEF B51 977.

34 “Suicide of a Craftsman on Christmas Eve," Tribune de la Manche, 30 December 1977.

35 “When Men Are Nameless,” La Manche libre, 8 January 1978.

${ }^{36}$ See his editorial entitled "Administrative terror," Le Nouvel Économiste, 9 January 1978.

${ }^{37}$ Le Monde, 8 April 1978.

38 “The Tax Dragoons," Le Point, 15 December 1975, 68.

${ }^{39}$ Television news of Antenne 2, 29 November 1976, INA archives.

${ }^{40}$ See Le Monde, 5 November 1975.

${ }^{41}$ The Inspection générale des services was created by the council of ministers on 13 July 1977.

${ }^{42}$ Alain Peyrefitte, Le mal français (Paris, 1976).

${ }^{43}$ Henri Lepage, Demain le libéralisme (Paris, 1980), 111. 
${ }^{44}$ Alexis Spire, Faibles et puissants face à l'impôt (Paris, 2012).

${ }^{45}$ Martin, The Permanent Tax Revolt, 17. 